\title{
Seafloor mapping reveals new features associated with halokinesis in the upper slope of Santos Basin
}

Raissa Basti Ramos, Mascimiliano Maly, Rodolfo Jasão Soares Dias, Michel Michaelovitch de Mahiques

Oceanographic Institute of the University of São Paulo, Brazil

Copyright 2021, SBGf - Sociedade Brasileira de Geofísica.

This paper was prepared for presentation during the $17^{\text {th }}$ International Congress of the Brazilian Geophysical Society held in Rio de Janeiro, Brazil, $16-19$ August 2021.

Contents of this paper were reviewed by the Technical Committee of the $17^{\text {th }}$ International Congress of the Brazilian Geophysical Society and do not necessarily represent any position of the SBGf, its officers or members. Electronic reproduction or storage of any part of this paper for commercial purposes without the written consent of the Brazilian Geophysical Society is prohibited.

\section{Abstract}

Since 2011 a series of multibeam and sub-bottom profiler surveys performed on the Santos Basin upper continental slope revealed the occurrence of several bottom features associated with the escape of gas from the seafloor. These features include pockmark fields and carbonate mound ridges. The integration of these data with deep- multichannel lines from the Brazilian Agency of Petroleum, Natural Gas and Biofuels revealed a direct or indirect influence of the halokinesis, via salt diapirs, walls, and pillows, as the primary mechanism for the formation of faults and fractures and the consequent upward displacement of gas.

In this work, we present three cases of seafloor features (a pockmark field, a rig-shaped carbonate ridge, and a perfectly aligned carbonate lineament) associated with halokinesis and gas escape. First, the relationship between halokinesis and bottom features was recognized via direct diapir exhumation, generation of radial faults associated with the uplift of diapirs, and development of fractures associated with salt movement at the Albian Gap.

Our research puts in evidence the need for systematic seafloor mapping for geo- and biodiversity, geohazards, and gas dynamics on the Brazilian continental margin.

This research was carried out in association with the ongoing R\&D project registered as ANP 21012-0, "MARINE LIFE - BMC - OIL AND GAS SEEPS (BIOIL)", (Universidade de São Paulo / Shell Brasil / ANP) Avaliação da Biologia e Geoquímica de Exsudações de Óleo e Gás na Costa Sudeste do Brasil, sponsored by Shell Brasil under the ANP R\&D levy as "Compromisso de Investimentos com Pesquisa e Desenvolvimento. Thanks are also due to the Brazilian Agency of Petroleum, Natural Gas and Biofuels (ANP) for providing the deep-seismic lines. 